\title{
THE LONG-LASTING SEARCH FOR A MODEL OF ECONOMIC DEVELOPMENT OF RUSSIA: ECONOMIC AND LEGAL DEVELOPMENT OF A COMPETITIVE STATE
}

\author{
Agnessa O. Inshakova \\ Volgograd State University, Volgograd, Russian Federation
}

Citation. Inshakova A.O. The Long-Lasting Search for a Model of Economic Development of Russia: Economic and Legal Development of a Competitive State. Legal Concept, 2019, vol. 18, no. 4, pp. 184-187. (in Russian).

УДК $34(470+571)$

Дата получения статьи: 30.09.2019

ББК 67.99(2Рoc)

Дата принятия статьи: 15.10 .2019

\section{ВЕКОВОЙ ПОИСК МОДЕЛИ ХОЗЯЙСТВЕННОГО РАЗВИТИЯ РОССИИ: ЭКОНОМИКО-ПРАВОВОЕ РАЗВИТИЕ КОНКУРЕНТОСПОСОБНОГО ГОСУДАРСТВА}

\author{
Агнесса Олеговна Иншакова \\ Волгоградский государственный университет, г. Волгоград, Российская Федерация
}

\begin{abstract}
Цитирование. Иншакова А. О. Вековой поиск модели хозяйственного развития России: экономикоправовое развитие конкурентоспособного государства // Legal Concept = Правовая парадигма. -2019. - Т. 18, № 4. - С. 184-187.
\end{abstract}

19-20 сентября 2019 г. в стенах Волгоградского государственного университета состоялась XVIII Международная научно-практическая конференция «Конкурентоспособная Россия: форсайт-модель экономического и правового развития в цифровую эпоху» памяти Олега Васильевича Иншакова (1952-2018).

Научное мероприятие было посвящено светлой памяти и научному наследию Заслуженного деятеля науки Российской Федерации, Заслуженного работника высшей школы Российской Федерации, доктора экономических наук, профессора Олега Васильевича Иншакова, ректора (1995-2014) и президента (2014-2016) Волгоградского государственного университета, директора НИИ социальноэкономического развития региона при ВолГУ (2016-2017), Почетного профессора Цзилинь- ского университета, Китай (2009), Почетного доктора Южного федерального университета (2014), Заслуженного профессора Волгоградского государственного университета (2017), Почетного профессора Института экономических исследований Дальневосточного отделения РАН (2017) - выдающегося российского экономиста, автора эволюционно-генетической теории факторов производства и модели «ядра развития» экономических систем, теории экономической генетики и наноэкономики, раскрывшего структуру динамики глобальных хозяйственных укладов на основе метапроизводственной функции; разработчика многокритериальной классификации институциональных экономических механизмов, общей модели циклического функционирования экономического механизма, теории гло- 
бальной экономической системы и расширения объекта и предмета экономической теории на основе эволюции ее уровневой структуры, широко представленных в публикациях в российских и зарубежных изданиях.

Конференция стала 18-й в цикле инициированных О.В. Иншаковым в 1998 г. научнопрактических конференций, объединяемых общей научной идеей, «Вековой поиск модели хозяйственного развития России», ключевым докладчиком на которых традиционно являлся Заслуженный деятель науки Российской Федерации О.В. Иншаков.

Организаторы конференции создали все условия для того, чтобы полученные О.В. Иншаковым научные результаты вновь послужили плодотворной методологической и теоретической основой для междисциплинарных исследований экономистов, юристов, историков, политологов, социологов и философов в рамках основных направлений конференции, предложенных для обсуждения в Волгоградском государственном университете в сентябре 2019 года. Представленные на конференции доклады, равно как и высказанные в них выводы и рекомендации, были нацелены на разработку междисциплинарного системного обеспечения конкурентоспособности Российской Федерации в условиях перехода к новому технологическому укладу и реализации цифрового сценария развития.

Основными дисциплинарными направлениями работы конференции стали экономические и юридические науки. Экономические исследования были направлены на выявление потенциала эволюционной и институциональной экономической теории в научном обосновании и реализации стратегии обеспечения конкурентоспособности современной России. Представители юридических наук обсуждали вопросы, раскрывающие системно-институциональное реформирование национального правопорядка как фактора конкурентоспособности российской экономики в условиях цифровизации.

В ходе конференции обсуждались такие вопросы, как: экономика экосистем; неоиндустриальная парадигма конкурентоспособного развития России; наноэкономика: феномен и экономико-социальный фактор конкурентоспособности России; формирование современной правовой модели превенции обхода закона как фактор повышения конкуренции субъектов предпринимательской деятельности, а также другие проблемы, связанные с необходимостью использования цифровых технологий в экономико-правовом регулировании в целях обеспечения конкурентоспособности России в условиях глобальной неоиндустриализации.

О высоком качестве проведенного научного мероприятия международного значения можно судить по высококвалифицированному составу программного и организационного комитетов, которые были представлены не только первыми лицами руководства вузов, но и ведущими учеными - представителями экономических и юридических наук, известными как в России, так и за рубежом, среди которых: заместитель научного руководителя Центрального экономико-математического института РАН, главный редактор журнала «Экономическая наука современной России» Г.Б. Клейнер; доктор юридических наук, профессор, зав. кафедрой международного права РУДН, Заслуженный юрист РФ, профессор кафедры международного права Международно-правового факультета МГИМО, член Комитета ООН по экономическим, социальным и культурным правам А.Х. Абашидзе; доктор экономических наук, профессор Западносаксонского университета прикладных наук, г. Цвиккау (Германия), Х.-К. Браувайлер; доктор экономических наук, профессор, заместитель губернатора Волгоградской области, председатель комитета промышленности и торговли Волгоградской области Р.С. Беков; доктор юридических наук, профессор, профессор кафедры гражданского и семейного права МГЮУ им. О.Е. Кутафина В.В. Долинская; доктор юридических наук, профессор, зав. кафедрой предпринимательского и корпоративного права МГЮУ им. О.Е. Кутафина, Заслуженный юрист РФ И.В. Ершова; доктор экономических наук, профессор, декан факультета управления Варшавского университета, г. Варшава (Польша), А.З. Новак; доктор экономических наук, декан факультета экономики и социальных наук Университета Святого Иштвана, г. Гёделле (Венгрия), Й. Капоста; доктор юридических наук, профессор, зав. кафедрой гражданского и международного частного права и гражданского процесса РУДН, Заслуженный юрист РФ Е.Е. Фролова; доктор экономических наук, профессор, 
президент АНО «Институт научных коммуникаций» Е.Г. Попкова; доктор экономических наук, профессор, председатель Научного совета «Центр общественных наук МГУ» МГУ им. М.В. Ломоносова, Заслуженный деятель науки РФ Ю.М. Осипов; доктор юридических наук, профессор, зав. кафедрой гражданского права КубГАУ, главный редактор журнала «Власть Закона», Заслуженный деятель науки Кубани В.П. Камышанский и др.

В составе программного и организационного комитетов Волгоградский государственный университет был представлен: ректором ВолГУ, доктором экономических наук, профессором В.В. Таракановым (председатель программного комитета); первым проректором ВолГУ, доктором экономических наук, профессором А.Э. Калининой (председатель организационного комитета); доктором юридических наук, профессором, зав. кафедрой гражданского и международного частного права ВолГУ А.О. Иншаковой (заместитель председателя программного комитета); доктором экономических наук, профессором, профессором кафедры экономической теории, мировой и региональной экономики ВолГУ, Заслуженным работником высшей школы РФ Е.И. Иншаковой (заместитель председателя организационного комитета); доктором экономических наук, профессором, директором института экономики и финансов ВолГУ, Заслуженным работником высшей школы РФ Е.Г. Руссковой; кандидатом юридических наук, доцентом, директором института права ВолГУ В.М. Шинкаруком; доктором юридических наук, профессором, профессором кафедры гражданского и международного частного права ВолГУ, Заслуженным деятелем науки Республики Калмыкия А.Я. Рыженковым; доктором юридических наук, профессором, профессором кафедры гражданского и международного частного права ВолГУ, членом Общественной палаты РФ, Заслуженным юристом РФ С.Ю. Казаченок и др.

В первый день работы в ходе пленарной сессии (19 сентября) были озвучены концептуальные направления работы конференции, представлена ретроспектива создания и развития конференции, названы ее основополагающие цели по годам, поставлены задачи и обозначены прогнозируемые результаты, в перечне которых, в частности, разработка парадигмы конкурентоспособного развития России в условиях цифровой экономики, формирование необходимого правового базиса с целью повышения конкурентоспособности российской экономики.

В течение двух дней конференции проводилась и активная работа тематических круглых столов. Так, под руководством Георгия Борисовича Клейнера, член-корреспондента РАН, доктора экономических наук, профессора, заместителя научного руководителя ЦЭМИ РАН, руководителя научного направления «Мезоэкономика, микроэкономика, корпоративная экономика», главного редактора журнала «Экономическая наука современной России», и при участии модератора Романа Михайловича Качалова, доктора экономических наук, профессора, заместителя главного редактора, ответственного секретаря редакционной коллегии журнала «Экономическая наука современной России», состоялся круглый стол «Концепция социально-экономических экосистем: актуальные проблемы восприятия молодыми исследователями».

Под руководством Юрия Михайловича Осипова, доктора экономических наук, профессора, председателя Научного совета «Центр общественных наук МГУ» МГУ им. М.В. Ломоносова, главного редактора научного журнала «Философия хозяйства», Заслуженного деятеля науки РФ, и при участии модераторов Михаила Михайловича Гузева, доктора экономических наук, профессора, заместителя директора Волжского филиала ВолГУ по научной работе, Сергея Васильевича Синякова, доктора экономических наук, профессора, Национального транспортного университета (г. Киев, Украина), и Виктора Валентиновича Кашицына, кандидата экономических наук, профессора Государственного морского университета им. адмирала Ф.Ф. Ушакова (г. Новороссийск), успешно прошла работа круглого стола «Конкурентоспособная Россия: философско-хозяйственное осмысление».

Модераторами круглого стола «Парадигма правового развития конкурентоспособного государства: стратегия и тактика» юридического профиля выступили Владимир Маркович Шинкарук, кандидат юридических наук, доцент, директор института права ВолГУ, Агнесса 
Олеговна Иншакова, доктор юридических наук, профессор, зав. кафедрой гражданского и международного частного права института права ВолГУ, главный редактор журнала ВАК «Legal Concept $=$ Правовая парадигма», руководитель НОЦ «Модернизация правовой системы современной России», и Александр Иванович Гончаров, доктор юридических наук, доктор экономических наук, профессор, профессор кафедры гражданского и международного частного права института права ВолГУ.

Параллельно с работой круглых столов состоялись мастер-классы «Концепция социально-экономических экосистем: актуальные проблемы восприятия молодыми исследователями» и «Взаимодействие экономики и права в условиях цифровизации», которые провели для молодых ученых, аспирантов и магистрантов ВолГУ специалисты в области экономики и права член-корреспондент РАН, доктор экономических наук, профессор Г.Б. Клейнер и доктор юридических наук, профессор, член Консультативного совета Верховного суда РФ В.В. Долинская (МГЮА им. О.Е. Кутафина). Лекторы поделились последними накопленными теоретическими знаниями по отраслям представляемых наук и результатами собственных научных изысканий в рамках заявленной темы. Участники мастер-класса имели уникальную возможность в режиме интерактивной беседы обменяться мнениями с ведущими учеными современности.

По результатам проведения конференции организаторы предоставили докладчикам и участникам возможность альтернативной публикации. Так, лучшие доклады в формате научных статей предложено опубликовать в жур- налах, входящих в перечень рецензируемых научных изданий Высшей аттестационной комиссией Министерства науки и образования РФ: «Вестник ВолГУ. Серия 3. Экономика. Экология» (https://ges.jvolsu.com/index.php/ru); «Региональная экономика. Юг России» (https:// re.volsu.ru); «Legal Concept $=$ Правовая парадигма» (https://j.jvolsu.com/index.php/ru/).

В качестве главного научного, публикуемого проекта, содержащего результаты работы конференции, организаторами мероприятия подготовлен сборник материалов конференции (на английском языке) «Competitive Russia: Foresight Model of Economic and Legal Development in the Digital Age - Proceedings of the International Scientific Conference in Memory of Oleg Inshakov (1952-2018)» - издание в составе серии книг «Lecture Notes in Networks and Systems» (издательство «Springer Nature Switzerland AG»), индексируемое в международных цитатно-аналитических базах Scopus, Web of Science.

Материалы, отобранные для публикации в подготовленной книге, разбиты на два раздела экономический «Improving the competitiveness of Russian economy in the new technologicalage: basic an dapplied research contribution» и юридический «Системно-институциональное реформирование национального правопорядка как фактор конкурентоспособности российской экономики в условиях цифровизации».

Статьи, представленные в сборнике, нацелены на изучение вопросов экономико-правового развития процессов неоиндустриализации, а также ключевых направлений развития национальной технологической инициативы, без которых конкурентоспособность любого современного государства стоит сегодня под вопросом.

\section{Information about the Author}

Agnessa O. Inshakova, Doctor of Sciences (Jurisprudence), Professor, Head of the Department of Civil and International Private Law, Volgograd State University, Base Department of the Southern Scientific Centre of the Russian Academy of Sciences, Prosp.Universitetsky, 100, 400062 Volgograd, Russian Federation, gimchp@volsu.ru, https://orcid.org/0000-0001-8255-8160

\section{Информация об авторе}

Агнесса Олеговна Иншакова, доктор юридических наук, профессор, заведующая кафедрой гражданского и международного частного права, Волгоградский государственный университет, базовая кафедра ЮНЦ РАН, просп. Университетский, 100, 400062 г. Волгоград, Российская Федерация, gimchp@volsu.ru, https://orcid.org/0000-0001-8255-8160 